\title{
Increased sensitivity to thyroid hormone in mice with complete deficiency of thyroid hormone receptor $\alpha$
}

\author{
Paolo E. Macchia*, Yoko Takeuchi ${ }^{\dagger}$, Tomoko Kawai ${ }^{\dagger}$, Kevin Cua*, Karine Gauthier ${ }^{\ddagger}$, Olivier Chassande ${ }^{\ddagger}$, Hisao Seo ${ }^{\dagger}$, \\ Yoshitaka Hayashi ${ }^{\dagger}$, Jacques Samarut ${ }^{\ddagger}$, Yoshiharu Murata ${ }^{\dagger}$, Roy E. Weiss*, and Samuel Refetoff*\$9\| \\ Departments of *Medicine and §Pediatrics and the IJ. P. Kennedy Jr. Mental Retardation Research Center, University of Chicago, MC 3090, \\ 5841 South Maryland Avenue, Chicago, IL 60637; ${ }^{\dagger}$ Research Institute of Environmental Medicine, University of Nagoya, \\ Nagoya 464-8601, Japan; and ${ }^{\ddagger}$ Centre National de la Recherche Scientifique, Unité Mixte de Recherche 49, \\ Institut National de la Recherche Agronomique, LA 913, Ecole Normale Supérieure, 69364 Lyon, France
}

Edited by J. E. Rall, National Institutes of Health, Bethesda, MD, and approved October 31, 2000 (received for review July 3, 2000)

Only three of the four thyroid hormone receptor (TR) isoforms, $\alpha 1, \beta 1$, and $\beta 2$, bind thyroid hormone (TH) and are considered to be true TRs. TR $\alpha 2$ binds to TH response elements on DNA, but its role in vivo is still unknown. We produced mice completely deficient in $\operatorname{TR} \alpha\left(\operatorname{TR} \alpha^{\mathrm{o} / \mathrm{o}}\right)$ that maintain normal serum thyroid-stimulating hormone (TSH) concentration despite low serum thyroxine $\left(T_{4}\right)$, suggesting increased sensitivity to TH. We therefore examined the effects of TH $\left(L-3,3^{\prime}, 5-\right.$ triiodothyronine, $\mathrm{L}-\mathrm{T}_{3}$ ) given to TH-deprived and to intact TR $\alpha^{\mathrm{o} / \mathrm{o}}$ mice. Controls were wild-type (WT) mice of the same strain and mice resistant to TH due to deficiency in $\operatorname{TR} \beta\left(\operatorname{TR} \beta^{-1-}\right)$. In liver, $T_{3}$ produced significantly greater responses in $\operatorname{TR} \alpha^{\mathrm{o} / \mathrm{o}}$ and smaller responses in $\mathrm{TR}^{-1-}$ as compared with WT mice. In contrast, cardiac responses to $\mathrm{L}-\mathrm{T}_{3}$ were absent or reduced in $\mathrm{TR} \alpha^{\mathrm{o} / \mathrm{o}}$, whereas they were similar in WT and TR $\beta^{-1-}$ mice, supporting the notion that TR $\alpha 1$ is the dominant TH-dependent TR isoform in heart. 5-Triiodothyronine (L-T3) given to intact mice produced a greater suppression of serum $T_{4}$ in $\mathrm{TR} \alpha^{\mathrm{o} / \mathrm{o}}$ than it did in WT mice and reduced by a greater amount the TSH response to TSH-releasing hormone. This is an in vivo demonstration that a TR deficiency can enhance sensitivity to TH. This effect is likely due to the abrogation of the constitutive "silencing" effect of $\operatorname{TR} \alpha 2$ in tissues expressing the TR $\beta$ isoforms.

$\mathbf{T}$ hyroid hormone $(\mathrm{TH})$ action is mediated through specific nuclear TH receptors (TRs) functioning as ligand-dependent transcription factors that increase or decrease the expression of target genes (1-3). There are two TR genes. The TR $\beta$ locus generates the $\beta 1$ and $\beta 2$ receptors by using two different promoters and alternative splicing. The TR $\alpha$ locus encodes TR $\alpha 1$, a molecule containing $410 \mathrm{aa}$, and three proteins that do not bind the ligand, triiodothyronine $\left(\mathrm{T}_{3}\right)$ (4-7) (GenBank accession no. AI322342). $\operatorname{TR} \alpha 2$, which results from an alternative splicing of the $\operatorname{TR} \alpha$ primary transcript, has 492 aa, the first 370 of which are identical to TR $\alpha 1$. TR $\Delta \alpha 1$ and TR $\Delta \alpha 2$, molecules of approximately 154 and 237 aa, respectively, are generated from an internal promoter located in intron 7 of the TR $\alpha$ locus (6). The function of TR $\alpha 2$, which has a wide tissue distribution (8), and that of TR $\Delta \alpha 1$ and $\mathrm{TR} \Delta \alpha 2$, found mainly in brain, gut, and lung (6), are still unknown. However, all have been shown to inhibit ligand-dependent transactivation of $\operatorname{TR} \beta$ and $\operatorname{TR} \alpha 1$, a phenomenon termed the dominant negative effect $(6,9-11, * *)$.

The relative contribution of the two TR gene products in mediating $\mathrm{TH}$ responses is poorly understood because of the paucity of information regarding in vivo function. In vitro DNA binding studies and functional assays in transfected cells have generated conflicting results concerning the specific effect of TR isoforms in gene regulation $(12,13)$. Interpretation is complicated, however, because data are derived from artificial systems using the overexpression of chimeric gene constructs that may not be faithful models of events occurring in the intact animal. The use of knockout mice that lack a particular TR isoform provides a powerful tool for exploring the relative contribution of each of the TR isoforms to the TH-mediated regulation of various biological processes in different tissues. The specific role of $\operatorname{TR} \alpha$ was investigated indirectly in mice deficient in $\operatorname{TR} \beta(14)$.
Results suggested that $\mathrm{TR} \alpha$ plays a major role in the regulation of heart rate and basal metabolism (15). This conclusion was confirmed and attributed to the TR $\alpha 1$ isoform (15).

Herein we examined the effects of $\mathrm{TH}$ deprivation and treatment with $\mathrm{L}-3,3^{\prime}, 5$-triiodothyronine $\left(\mathrm{L}-\mathrm{T}_{3}\right)$ on the pituitary, liver, and heart of homozygous mice deficient in all forms of TR $\alpha$ $\left(\mathrm{TR} \alpha^{\mathrm{o} / \mathrm{o}}\right)$. Compared with those of wild-type (WT) mice, the pituitary gland and liver of $\mathrm{TR} \alpha^{\mathrm{o} / \mathrm{o}}$ mice were more sensitive to $\mathrm{TH}$, whereas the same tissues of $\mathrm{TR} \beta$ knockout $\left(\mathrm{TR} \beta^{-/-}\right)$mice, as previously shown, were resistant to $\mathrm{TH}$. In contrast, the heart of $\mathrm{TR} \alpha^{\mathrm{o} / \mathrm{o}}$ mice was hyporesponsive to $\mathrm{TH}$, indicating that $\mathrm{TR} \alpha$ is the predominant TR form expressed in this tissue. Given that TR $\alpha 1$ knockout mice have no increased sensitivity to TH (16), our results suggest that TR $\alpha 2$ exerts a dominant negative effect in some tissues in vivo and that the absence of TR $\alpha 2$ enhances sensitivity to $\mathrm{TH}$.

\section{Experimental Methods}

Animal Procedures. As is the case with the TR $\alpha^{-/-}$mouse (17), the $\mathrm{TR} \alpha^{\mathrm{o} / \mathrm{o}}$ mouse is deficient in both TR $\alpha 1$ and TR $\alpha 2$ encoded by the $T R \alpha$ gene, but, in addition, it lacks the shorter transcripts initiated from the internal promoter located in intron 7 (6). However, the gene sequence for Rev-erbA $\alpha$, the TR-related protein encoded by the opposite strand of $\operatorname{TR} \alpha(18,19)$, remains intact. In contrast to the TR $\alpha^{-/-}$mice, the $\mathrm{TR} \alpha^{\mathrm{o} / \mathrm{o}}$ mice survive without rescue by $\mathrm{TH}$ treatment. They are fertile but have a slightly slower growth rate. Thus the dose of $\mathrm{L}-\mathrm{T}_{3}$ was adjusted to the body weight (BW). Mice resistant to $\mathrm{TH}$ due to deletion of the TR $\beta$ gene (TR $\beta^{--}$) (described in ref. 20) were used for comparison. The $\mathrm{TR} \beta^{-1-}$ mice were derived after nine crossings of $\mathrm{TR} \beta^{-/+}$heterozygote with WT mice of the C57BL/6J strain before inbreeding. TR $\alpha^{\mathrm{o} /+}$ mice were crossed four times with WT mice of the same strain before heterozygotes were intercrossed. Breeding of the resulting homozygotes $\mathrm{TR} \alpha^{\mathrm{o} / \mathrm{o}}$ and $\mathrm{TR} \alpha^{+/+}$(WT) mice was used in the grouped experiments.

Mice were weaned in the fourth week after birth and were fed rodent diet containing $0.53 \mathrm{ppm}$ iodine (no. 5053; LabDiet, Brentwood, MO) ad libitum and given tap water. All animal

This paper was submitted directly (Track II) to the PNAS office.

Abbreviations: $\mathrm{TH}$, thyroid hormone; $\mathrm{TR}$, $\mathrm{TH}$ receptor; $\mathrm{TH}$, thyroid hormone; $\mathrm{TSH}$, thyroidstimulating hormone; $T_{4}$, thyroxine; $\mathrm{L}-\mathrm{T}_{3}, \mathrm{~L}-3,3^{\prime}, 5$-triiodothyronine; $\mathrm{BW}$, body weight; TRH, TSH-releasing hormone; 5'DI, iodothyronine type I 5'-deiodinase; ME, malic enzyme; SERCA2, sarcoplasmic reticulum calcium adenosine triphosphatase; PTU, 5-propyl-2-thiouracil; WT, wild-type.

ITo whom reprint requests should be addressed. E-mail: refetoff@medicine.uchicago. bsd.edu.

**This paper was presented in part at the 82 nd Annual Meeting of the Endocrine Society,

June 21-24, 2000, Toronto, Canada, and selected as a finalist for the Knoll Award.

The publication costs of this article were defrayed in part by page charge payment. This article must therefore be hereby marked "advertisement" in accordance with 18 U.S.C. $\$ 1734$ solely to indicate this fact.

Article published online before print: Proc. Natl. Acad. Sci. USA, 10.1073/pnas.011306998. Article and publication date are at www.pnas.org/cgi/doi/10.1073/pnas.011306998 
Table 1. Thyroid function tests and heart rate in adult male TR $\alpha^{\circ / 0}$ mice as compared with WT and $\operatorname{Tr} \boldsymbol{\beta}^{-/-}$controls

\begin{tabular}{lcccc} 
& $\begin{array}{c}\mathrm{TSH}, \\
\mathrm{mU} / \text { liter }\end{array}$ & $\begin{array}{c}\mathrm{T}_{4,} \\
\mu \mathrm{g} / \mathrm{dl}\end{array}$ & $\begin{array}{c}\mathrm{T}_{3,} \\
\mathrm{ng} / \mathrm{dl}\end{array}$ & $\begin{array}{c}\text { Heart rate, } \\
\text { beats per } \mathrm{min}\end{array}$ \\
\hline $\mathrm{TR} \alpha^{\mathrm{o} / \mathrm{o}}$ & $22 \pm 3.5$ & $3.29 \pm 0.09$ & $96.1 \pm 7.2$ & $358 \pm 22$ \\
$\mathrm{WT}$ & $(32)$ & $(31)$ & $(11)$ & $(23)$ \\
& $25 \pm 3.0$ & $3.76 \pm 0.10$ & $83.6 \pm 3.0$ & $470 \pm 6$ \\
$\mathrm{TR} \beta^{-/-}$ & $(54)$ & $(47)$ & $(13)$ & $(43)$ \\
& $136 \pm 18$ & $7.78 \pm 0.33$ & $142.3 \pm 12.4$ & $522 \pm 8$ \\
$P\left(\mathrm{TR} \alpha^{\circ} / \mathrm{o}\right.$ vs. WT $)$ & $(42)$ & $(37)$ & $(12)$ & $(48)$ \\
$P\left(\mathrm{TR} \alpha^{\circ} / \mathrm{o}\right.$ vs. TR $\left.\beta^{-/-}\right)$ & $\mathrm{NS}$ & $<0.005$ & $\mathrm{NS}$ & $<0.0001$ \\
\hline
\end{tabular}

The number of animals is in parentheses. NS, not significant.

experiments were performed at the University of Chicago according to protocols approved by the Institutional Animal Care and Use Committee.

Because of sex and age differences in serum thyroidstimulating hormone $(\mathrm{TSH})$ and thyroxine $\left(\mathrm{T}_{4}\right)$ concentrations, all mice were male and were 60-70 days old at the beginning of each experiment. The $\mathrm{BW}$ of $\mathrm{TR} \alpha^{\mathrm{o} / \mathrm{o}}$ mice (mean $\pm \mathrm{SEM}$ ) of $18.4 \pm 0.4 \mathrm{~g}$ was significantly lower $(P<0.0001)$ than that of the WT $(23.4 \pm 0.5 \mathrm{~g})$ and $\mathrm{TR} \beta^{-/-}$mice $(22.0 \pm 0.4 \mathrm{~g})$. Experiments were terminated by exsanguination under methoxyflurane (Pitman-Moore, Mundelein, IL) anesthesia. Livers were completely removed, weighed, cut into $0.2-0.5$-g pieces, and frozen on dry ice before storage at $-85^{\circ} \mathrm{C}$. Atria were removed and heart ventricles were immediately frozen and stored at $-85^{\circ} \mathrm{C}$.

Induction of Hypothyroidism and Treatment with TH. TH deficiency was induced in 10-14 male mice of each type (TR $\alpha^{\mathrm{o} / \mathrm{o}}, \mathrm{WT}$, and $\operatorname{TR} \beta^{-/-}$) with a low-iodine diet containing $0.15 \%$ 5-propyl-2thiouracil (PTU), as described (21). On the 11th day, animals of each type were split into two groups. One group received daily i.p. injections of $2 \mu \mathrm{g}$ of $\mathrm{L}-\mathrm{T}_{3} / 100 \mathrm{~g} \mathrm{BW} /$ day for 4 days, whereas the other group received only the vehicle. The PTU diet was given throughout the $\mathrm{L}-\mathrm{T}_{3}$ and vehicle treatment period. The concentration of $\mathrm{L}_{-} \mathrm{T}_{3}$ was confirmed by radioimmunoassay. Experiments were terminated $12-16 \mathrm{~h}$ after the last injection. In a separate experiment, groups of 4-5 mice were similarly treated and blood was collected for serum $\mathrm{T}_{3}$ determination $24 \mathrm{~h}$ after the penultimate $\mathrm{L}_{-} \mathrm{T}_{3}$ dose and at $2,4,8$, and $16 \mathrm{~h}$ after the last $\mathrm{L}-\mathrm{T}_{3}$ injection. Note that separate animals were used for the 2and 8-h and 4- and 16-h posttreatment blood sampling.

In a separate experiment, $\mathrm{L}_{-} \mathrm{T}_{3}$ was given on the same schedule to groups of mice of each type (10 WT and $\left.7 \mathrm{TR} \alpha^{\mathrm{o} / \mathrm{o}}\right)$ with no prior induction of hypothyroidism. Two incremental doses were given consecutively as described (22), $0.2 \mu \mathrm{g} / 100 \mathrm{~g} \mathrm{BW} /$ day, followed by $0.8 \mu \mathrm{g} / 100 \mathrm{~g} \mathrm{BW} /$ day. Blood samples (approximately $300 \mu \mathrm{l}$ ) were obtained from the tail vein before the treatment (baseline) and 12-16 $\mathrm{h}$ after the last injection of each incremental $\mathrm{L}-\mathrm{T}_{3}$ dose.

The suppressive effect of TH on the response of TSH to TSH-releasing hormone (TRH) was examined in WT and TR $\alpha^{\mathrm{o} / \mathrm{o}}$ mice. Three groups of 5-6 animals of each type were given the two doses of $\mathrm{L}_{-} \mathrm{T}_{3}$ or the vehicle only (basal) for 4 days. On the fifth day, 12-16 $\mathrm{h}$ after the last injection, blood samples were obtained before and $15 \mathrm{~min}$ after the i.p. administration of $0.275 \mu \mathrm{g}$ TRH.

Measurements in Serum Samples. Cholesterol levels were measured with an autoanalyzer as described. Serum TSH was measured with a sensitive radioimmunoassay (23), and results were expressed in bioassayable TSH units. Serum total $\mathrm{T}_{4}$ and $\mathrm{T}_{3}$ concentrations were measured by radioimmunoassays (Diagnostic Products, Los Angeles). The sensitivities of these assays were $0.2 \mu \mathrm{g} \mathrm{T}_{4} / \mathrm{dl}$ and $20 \mathrm{ng} \mathrm{T}_{3} / \mathrm{dl}$.
Heart Rate. Electrocardiograms were recorded under chloral hydrate anesthesia (4 mg/10 g BW i.p.) with mice placed in a water bed maintained at $37^{\circ}-38^{\circ} \mathrm{C}$. A Hewlett-Packard monitor/terminal (model 78534AA) with a chart speed of $25 \mathrm{~mm} / \mathrm{s}$ was used.

Tissue Analyses. $\mathrm{T}_{3}$ binding to liver nuclei was determined as described (15). Pools of approximately $1 \mathrm{~g}$ of frozen liver pieces from at least four animals of each type were used. All animals had received the PTU diet for 14 days and were, thus, hypothyroid before liver collection. $\mathrm{T}_{3}$ binding affinity and maximal binding capacity were determined by the method of Scatchard. The former was corrected for DNA content.

Northern analyses were performed on RNA extracted from tissues of individual animals. Total RNA was prepared by the acid-guanidinium thiocyanate-phenol-chloroform method (24) from livers and heart ventricles frozen 1-3 min after death and kept at $-85^{\circ} \mathrm{C}$. Fifteen micrograms of total RNA was denatured and fractionated by electrophoresis on $0.8 \%$ agarose gel, transferred onto GeneScreen Plus (DuPont/NEN), using VacuGene (Amersham Pharmacia). cDNA probes for iodothyronine type I $5^{\prime}$ deiodinase (5'DI) (25), malic enzyme (ME) (26), and sarcoplasmic reticulum calcium adenosine triphosphatase (SERCA2) [prepared by reverse transcription-PCR with the sense (5'-ACGATCTGTGCTCTGTGTAATGACTCT-3') and antisense (5'-GCGCGTCGTTCACACCATCACCAGTCA-3') oligonucleotides] were labeled with $\left[\gamma^{32} \mathrm{P}\right]$ deoxycytidine triphosphate (specific activity 111 $\mathrm{Bq} / \mathrm{mmol}$ ) (DuPont/NEN), using the Random Primed DNA Labeling Kit (Roche Molecular Biochemicals). Hybridization and subsequent washing procedures were carried out as described (27). The quantity of mRNA on radiographs was measured with a molecular imager (Bio-Rad).

To assess the uniformity in RNA transfer among samples, hybridized membranes were reprobed with a cDNA complementary to rRNA. To correct the results of Northern blots, the activity of rRNA probe hybridized to each lane was divided by the average activity of rRNA for the entire group. These ratios were used to correct the activity of the respective mRNA abundance in each lane.

Data Presentation and Statistical Analysis. Values are reported as mean \pm SE. $P$ values were calculated by two-way ANOVA or Student's $t$ test when comparisons were made within the same genotype. Values corresponding to the respective limits of the assay sensitivities were assigned to samples that measured below the detectable range. Outliers were identified by a two-tailed test with a significance level of $<0.05(28,29)$. No more than one outlier per treatment group was removed. One $\mathrm{TR} \beta^{-1-}$ mouse did not achieve a sufficient degree of hypothyroidism with the PTU diet, as determined by a serum TSH level of 725 milliunits/liter and a $\mathrm{T}_{4}$ of $5.3 \mu \mathrm{g} / \mathrm{dl}$, both 10 -fold below and above the group means. All data generated from this mouse were excluded. Statistics were 


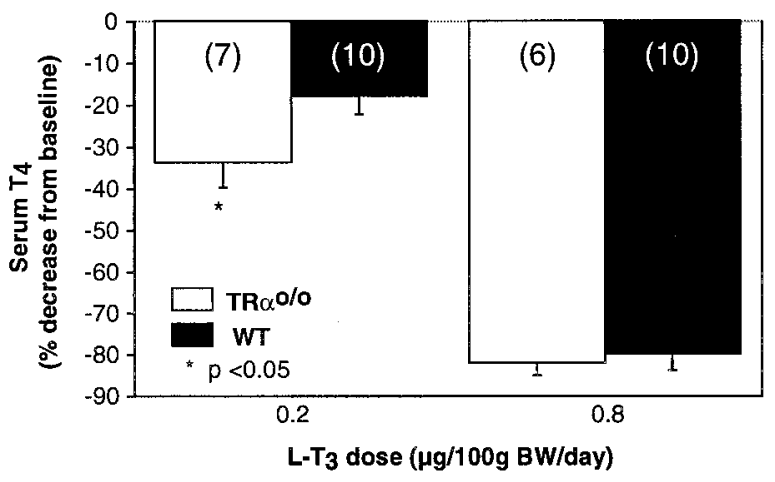

Fig. 1. Effect of TH on the feedback suppression of thyroid function. TR $\alpha^{0 / 0}$ and WT mice were treated with two incremental doses of L-T $\mathrm{T}_{3}$ each for 4 consecutive days. The decrease in serum $\mathrm{T}_{4}$ was expressed as a percentage of the baseline values measured in the same mice before $\mathrm{L}_{-} \mathrm{T}_{3}$ treatment. Note the greater suppression of $T_{4}$ in TR $\alpha^{0 / 0}$ mice receiving the lower $L-T_{3}$ dose. The numbers of animals are in parentheses.

performed using STATVIEW 5.0 software (Abacus Concepts, Berkeley, CA).

\section{Results}

Thyroid Function Tests and Heart Rate at Baseline in $\operatorname{TR} \alpha^{0 / 0}$ Mice as Compared with WT and TR $\boldsymbol{\beta}^{-1-}$ Mice. Results of thyroid function tests in untreated $\mathrm{TR} \alpha^{\mathrm{o} / \mathrm{o}}$ are compared with those in WT and $\operatorname{TR} \beta^{-1-}$ mice (Table 1). Despite the similar levels of circulating $\mathrm{TSH}, \mathrm{TR} \alpha^{\mathrm{o} / \mathrm{o}}$ mice have significantly lower levels of total $\mathrm{T}_{4}$ $(3.29 \pm 0.09 \mu \mathrm{g} / \mathrm{dl})$ compared with WT animals $(3.76 \pm 0.10$ $\mu \mathrm{g} / \mathrm{dl}, P<0.005)$. As previously reported $(14,21)$, the $\mathrm{TR} \beta^{-1-}$ animals were resistant to $\mathrm{TH}$ and had increased levels of serum $\mathrm{T}_{4}$ and $\mathrm{T}_{3}$ as well as TSH concentration. The mean basal heart rate of $\operatorname{TR} \alpha^{\mathrm{o} / \mathrm{o}}$ mice was significantly lower than that of WT mice, a finding similar to that reported for mice lacking only the TR $\alpha 1$ isoform (16). The higher heart rate in $\mathrm{TR} \beta^{-1-}$ mice is as reported previously $(15,30)$ and is consistent with the higher serum $\mathrm{TH}$ levels in these animals.

Sensitivity of Serum TSH to the Feedback Regulation by TH. The observation of a small, but significant, decrease in serum $\mathrm{T}_{4}$ concentration not associated with an alteration in basal serum TSH values could be explained by reduced $\mathrm{T}_{4}$ binding to serum proteins, mild hypothyroidism, or increased sensitivity to $\mathrm{TH}$. To determine the physiological significance of this observation, groups of mice were given two incremental doses of $\mathrm{L}-\mathrm{T}_{3}$, and the suppressive effect on serum $\mathrm{T}_{4}$ was examined (Fig. 1). In addition, because the basal serum TSH concentrations were too low for accurate measurement of a decrease induced by $\mathrm{L}_{-} \mathrm{T}_{3}$, the $\mathrm{TSH}$ response $15 \mathrm{~min}$ after the administration of TRH was determined (Fig. 2).

Treatment with $0.2 \mu \mathrm{g} \mathrm{L}-\mathrm{T}_{3} / 100 \mathrm{~g} \mathrm{BW}$ brought the serum $\mathrm{T}_{4}$ of $\mathrm{TR} \alpha^{\mathrm{o} / \mathrm{o}}$ animals to $2.26 \pm 0.01 \mu \mathrm{g} / \mathrm{dl}$ as compared with $3.01 \pm$ $0.11 \mu \mathrm{g} / \mathrm{dl}$ in WT animals. This represents a reduction of $34.0 \pm$ $5.4 \%$ and $18.2 \pm 3.7 \%$, respectively $(P<0.05)$. Treatment with the higher dose of $0.8 \mu \mathrm{g} \mathrm{L}-\mathrm{T}_{3} / 100 \mathrm{~g} \mathrm{BW} /$ day for 4 more days produced the same degree of serum $\mathrm{T}_{4}$ suppression in the two types of mice (Fig. 1).

The response of TSH to TRH before $\mathrm{TH}$ treatment and its suppression after the administration of the same two doses of ${\mathrm{L}-\mathrm{T}_{3}}_{3}$ are shown in Fig. 2. In animals not given $\mathrm{L}_{-} \mathrm{T}_{3}$, the incremental TSH response to TRH was not different in $\mathrm{TR} \alpha^{\mathrm{o} / \mathrm{o}}$ mice compared with WT mice but was significantly lower in $\mathrm{TR} \beta^{-1-}$ mice $(P<0.01)$. The higher dose of $\mathrm{L}-\mathrm{T}_{3}$ suppressed the $\mathrm{TSH}$ response by $77.3 \pm 5.7 \%$ in the $\mathrm{TR} \alpha^{\mathrm{o} / \mathrm{o}}$ mice as compared with $42.8 \pm 15.8 \%$ in WT mice $(P=0.02)$. Collectively, these
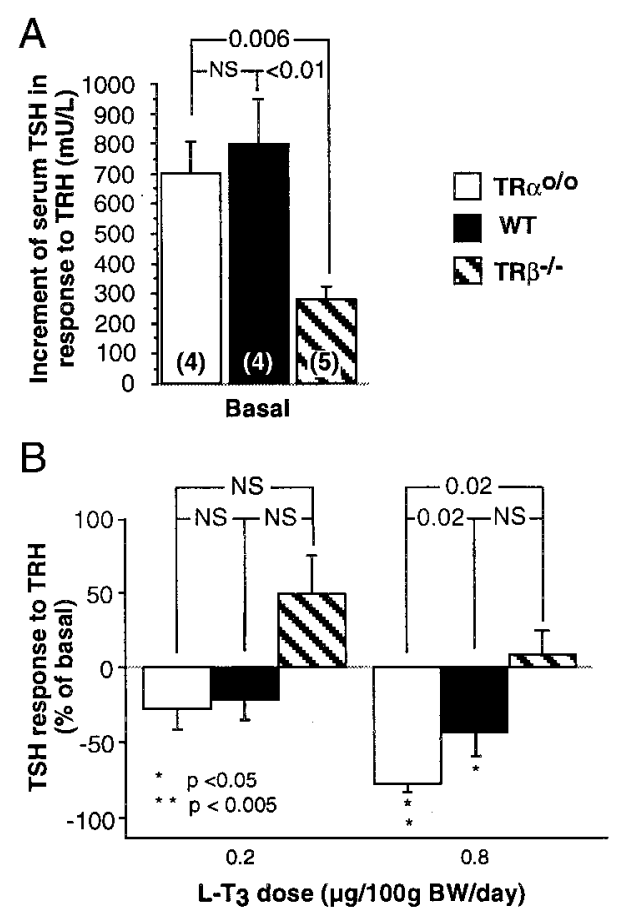

Fig. 2. Effect of TH on the TSH response to TRH. Groups of mice from the three genotypes were treated for 4 days with two different doses of $\mathrm{L}-\mathrm{T}_{3}$ or with the vehicle only. TSH was measured before and $15 \mathrm{~min}$ after the administration of TRH. (A) TSH response to TRH in mice not given $\mathrm{L}_{-} \mathrm{T}_{3}$ (basal response). ( $B) \mathrm{TSH}$ responses to TRH in mice given $\mathrm{L}^{-\mathrm{T}_{3}}$, expressed as a percentage of the basal response. Note the paradoxical increase in TR $\beta^{-1-}$ mice receiving $0.2 \mu \mathrm{g} \mathrm{L}-\mathrm{T}_{3} / 100 \mathrm{~g} \mathrm{BW}$ and the greater suppressive effect of $0.8 \mu \mathrm{g}$ $\mathrm{L}-\mathrm{T}_{3} / 100 \mathrm{~g} \mathrm{BW}$ in TR $\alpha^{\mathrm{o} / \mathrm{o}}$ mice. In $A$, the number of animals in each group is in parentheses. In $B$, data for each bar are derived from five or six animals. $P$ values indicated by * are differences in responses after $\mathrm{L}-\mathrm{T}_{3}$ treatment as compared with baseline. $P$ values above bars were obtained by two-way ANOVA of original numerical data.

data indicate that the feedback regulation of the pituitarythyroid axis of $\mathrm{TR} \alpha^{\mathrm{o} / \mathrm{o}}$ mice is more sensitive to $\mathrm{TH}$.

Of interest is the lower response of TSH to TRH at baseline in $\operatorname{TR} \beta^{-1-}$ mice and the $49.2 \pm 26.3 \%$ paradoxical response in these mice given the lower dose of $\mathrm{L}_{-} \mathrm{T}_{3}$. Similar findings were reported 20 years ago with a comparable dose of $\mathrm{L}_{-} \mathrm{T}_{3}(31)$ given to humans homozygous for TR $\beta$ gene deletion (32).

Thyroid Function in TH-Deprived and TH-Treated Mice. To investigate the role of TR $\alpha$ in the mediation of TH action, mice were studied during TH deprivation and after supplementation with TH. The dose of $2 \mu \mathrm{g} \mathrm{L}-\mathrm{T}_{3} / 100 \mathrm{~g} \mathrm{BW}(0.5 \mu \mathrm{g} / 25 \mathrm{~g}$ mouse $)$ has been shown to be effective in bringing the high serum TSH of hypothyroid WT mice to normal, inducing metabolic effects, and producing changes in liver $(15,21,33)$. This investigative approach served two purposes. First, it allowed determination of the tissue responses of $\mathrm{TR} \alpha^{\mathrm{o} / \mathrm{o}}$ mice to the same amount of $\mathrm{TH}$ as in WT and $\operatorname{TR} \beta^{-1-}$ mice, which, under basal conditions, have different serum concentrations of TH. Second, observations under the conditions of $\mathrm{TH}$ deprivation and full replacement provided a measure of the maximal physiological effect of TH.

The three genotypes that received the PTU diet only had similar serum TSH, $\mathrm{T}_{4}$, and $\mathrm{T}_{3}$ levels (Table 2 ). $\mathrm{L}_{-} \mathrm{T}_{3}$ treatment produced a greater suppression of serum TSH in the TR $\alpha^{\mathrm{o} / \mathrm{o}}$ mice than in the WT animals, a difference that did not reach statistical significance. As expected, the effect on $\mathrm{TR} \beta^{-/-}$mice was lesser, reflecting their decreased sensitivity to TH (Table 2).

Serum $\mathrm{T}_{3}$ concentrations achieved at different times after the 
Table 2. Thyroid function tests in TR $\alpha^{\circ / 0}, W T$ and TR $\beta^{-/-}$mice after treatment with PTU and PTU $+T_{3}$

\begin{tabular}{|c|c|c|c|c|c|c|}
\hline & \multicolumn{3}{|c|}{ PTU* } & \multicolumn{3}{|c|}{$\mathrm{PTU}+\mathrm{T}_{3}{ }^{\dagger}$} \\
\hline & $\mathrm{TSH}, \mathrm{mU} /$ liter & $\mathrm{T}_{4}, \mu \mathrm{g} / \mathrm{dl}$ & $\mathrm{T}_{3}, \mathrm{ng} / \mathrm{dl}$ & $\mathrm{TSH}, \mathrm{mU} / \mathrm{L}$ & $\mathrm{T}_{4}, \mu \mathrm{g} / \mathrm{dl}$ & $\mathrm{T}_{3}, \mathrm{ng} / \mathrm{dl}$ \\
\hline $\operatorname{TR} \alpha^{\circ / \circ}$ & $10,650 \pm 1,900$ & $0.71 \pm 0.08$ & $50 \pm 8$ & $8 \pm 1.5$ & $0.37 \pm 0.04$ & $147 \pm 24$ \\
\hline $\operatorname{TR} \beta^{-/-}$ & $10,300 \pm 1,850$ & $0.93 \pm 0.11$ & $34 \pm 11$ & $274 \pm 83$ & $0.95 \pm 0.08$ & $142 \pm 46$ \\
\hline$P\left(\mathrm{TR} \alpha^{\mathrm{o} / \mathrm{o}}\right.$ vs. WT $)$ & NS & NS & NS & NS & NS & NS \\
\hline$P\left(\operatorname{TR} \alpha^{\mathrm{o} / \mathrm{o}} \mathrm{vs} . \mathrm{TR} \beta^{-/-}\right)$ & NS & NS & NS & $<0.01$ & $<0.0001$ & NS \\
\hline
\end{tabular}

NS, not significant.

*Fifteenth day of treatment with PTU.

${ }^{\dagger}$ At the termination of the experiment, after 4 days of $\mathrm{L}-\mathrm{T}_{3}$ treatment, except for the $\mathrm{T}_{3}$ value measured $24 \mathrm{~h}$ after the third and penultimate dose of $\mathrm{L}-\mathrm{T}_{3}$.

administration of $\mathrm{L}-\mathrm{T}_{3}$ were not different among the animals of the three genotypes (Table 2 and Fig. 3).

Role of TR $\alpha$ in the Mediation of TH Action on Liver. Four known markers of $\mathrm{TH}$ action were measured during $\mathrm{TH}$ deprivation and after its supplementation as described above. L- $\mathrm{T}_{3}$ treatment reduced the liver weight of $\mathrm{WT}$ and $\mathrm{TR} \alpha^{\mathrm{o} / \mathrm{o}}$ mice but, as expected (33), had no effect on the $\operatorname{TR} \beta^{-1-}$ animals. However, the decrease was greater in $\mathrm{TR} \alpha^{\mathrm{o} / \mathrm{o}}$ mice than in WT mice $(P<$ 0.005) (Fig. 4). TR $\alpha^{\mathrm{o} / \mathrm{o}}$ mice had a significantly higher reduction in cholesterol after treatment with $\mathrm{L}^{-\mathrm{T}_{3}}$ as compared with WT animals $(P<0.005)$. In contrast, and as expected $(15)$, the $\mathrm{T}_{3}$-mediated reduction in serum cholesterol was significantly smaller in TR $\beta^{-1-}$ mice $(P<0.0001)$ (Fig. 3).

$5^{\prime} D I$ and $M E$ are well characterized TH-responsive genes, the transcriptional regulations of which have been extensively studied in the rat $(3,34)$ and have been shown to undergo similar changes in response to $\mathrm{L}-\mathrm{T}_{3}$ in the mouse $(15,33)$. cDNAs of these two genes were used to determine their mRNA content in the liver of TR $\alpha^{\mathrm{o} / \mathrm{o}}$, WT, and TR $\beta^{-1-}$ mice by Northern blotting (Fig. 5). TH deprivation abolished the ability to detect 5'DI mRNA, even after prolonged exposure of the hybridized membranes. $\mathrm{L}-\mathrm{T}_{3}$ treatment produced a significantly greater increase in the abundance of the mRNA of this enzyme in TR $\alpha^{\mathrm{o} / \mathrm{o}}$ mice as compared with WT animals and a much smaller increase in $\operatorname{TR} \beta^{-1-}$ mice $(P<0.005$ and $<0.0001$, respectively). ME mRNA was also significantly $(P<$ 0.001 ) higher in $\mathrm{TR} \alpha^{\mathrm{o} / \mathrm{o}}$ than in WT mice under $\mathrm{L}-\mathrm{T}_{3}$ treatment.

Quantification of $\mathbf{T}_{\mathbf{3}}$ Binding TR in Liver. To determine whether the absence of $\operatorname{TR} \alpha$ produces a compensatory increase in $\operatorname{TR} \beta, \mathrm{T}_{3}$ binding studies were carried out in liver nuclei. The maximal $\mathrm{T}_{3}$ binding capacity in three separate experiments averaged 144

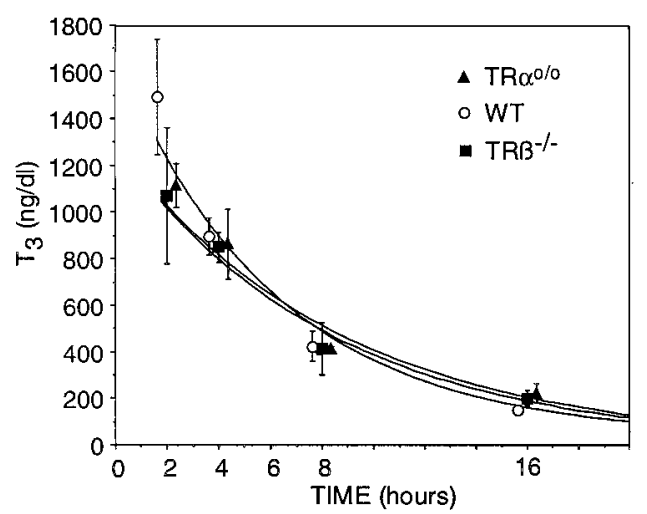

Fig. 3. Serum $T_{3}$ concentrations at different times after the administration of $\mathrm{L}-\mathrm{T}_{3}$. Blood was obtained at the indicated times after the fourth i.p. dose of $\mathrm{L}^{-} \mathrm{T}_{3}$ on the last day of the experiment. Values are not significantly different among the three genotypes at each time point. fmol/100 $\mu \mathrm{g}$ DNA for livers of WT animals. The corresponding values in $\mathrm{TR} \alpha^{\mathrm{o} / \mathrm{o}}$ and $\mathrm{TR} \beta^{-/-}$mice were, respectively, $66 \%$ and $21 \%$ of the WT. These results indicate that deficiency in one of the $T R$ genes does not produce a compensatory increase in the other. The relative contributions of $\operatorname{TR} \beta$ and $\operatorname{TR} \alpha 1$ in the liver of mice are similar to those reported in the rat (35).

Responses to TH of Heart Rate and TH-Responsive Genes Expressed in Heart. Compared with baseline, TH deprivation decreased the heart rate of both WT and TR $\beta^{-1-}$ mice but had no effect on $\mathrm{TR} \alpha^{\mathrm{o} / \mathrm{o}}$ mice $(358 \pm 22$ vs. $335 \pm 20$ beats $/ \mathrm{min}) . \mathrm{L}^{-\mathrm{T}_{3}}$ treatment produced an increase in heart rate in WT and TR $\beta^{-1-}$ mice $(89 \pm 8 \%$ and $66 \pm 4 \%)$ that was significantly higher in relative magnitude than that in $\mathrm{TR} \alpha^{\mathrm{o} / \mathrm{o}}$ mice $(27 \pm 7 \%)$ (Fig. $\left.6 A\right)$.

Relative to the state of $\mathrm{TH}$ deprivation, $\mathrm{L}_{-} \mathrm{T}_{3}$ produced a modest increase in cardiac SERCA2 mRNA in the WT and $\mathrm{TR} \beta^{-1-}$ mice but not in the TR $\alpha^{\mathrm{o} / \mathrm{o}}$ mice $(P<0.001)$ (Fig. $\left.6 B\right)$.

\section{Discussion}

$\mathrm{TH}$ exerts its effects through interaction with specific nuclear TRs, $\alpha 1, \beta 1$, and $\beta 2$ (36), that regulate the expression of target genes by binding to cognate $\mathrm{TH}$ response elements, either as homodimers or as heterodimers in association with retinoid $\mathrm{X}$ receptors $(37,38)$. Because both $T R \alpha$ and $T R \beta$ genes are expressed in most tissues (8), either one or both can be implicated in mediating in vivo the TH-dependent effects.
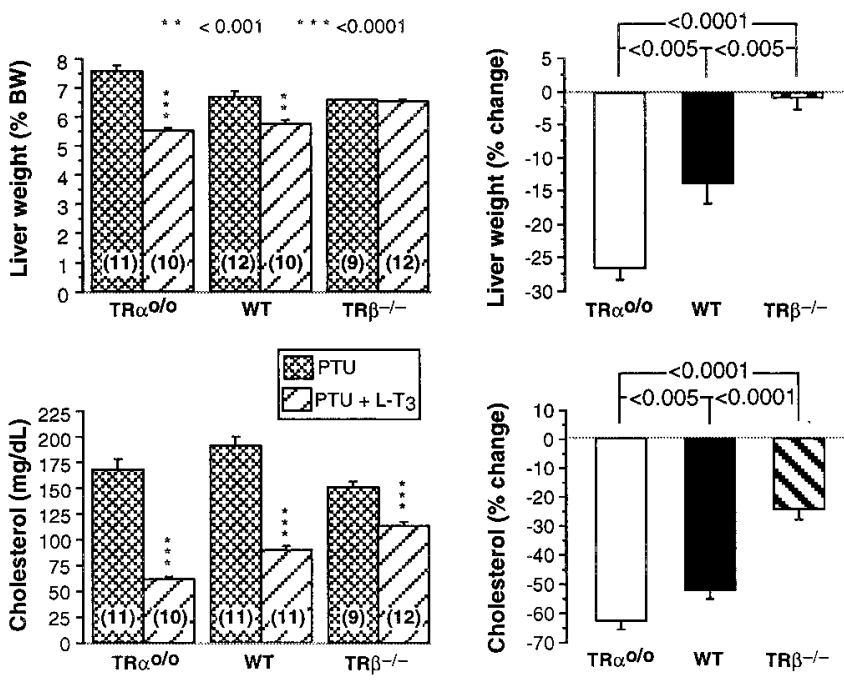

Fig. 4. Effect $\mathrm{TH}$ deprivation and $\mathrm{L}-\mathrm{T}_{3}$ treatment on liver weight and serum cholesterol. Groups of mice from the three genotypes were TH-deprived (PTU) and then treated with TH (PTU + T3). Shown are measured values (Left) and the percent changes induced by ${\mathrm{L}-\mathrm{T}_{3}}_{3}$ treatment (Right). Note the greater relative response to $\mathrm{TH}$ of $\mathrm{TR} \alpha^{\mathrm{o} / \mathrm{o}}$ mice. 

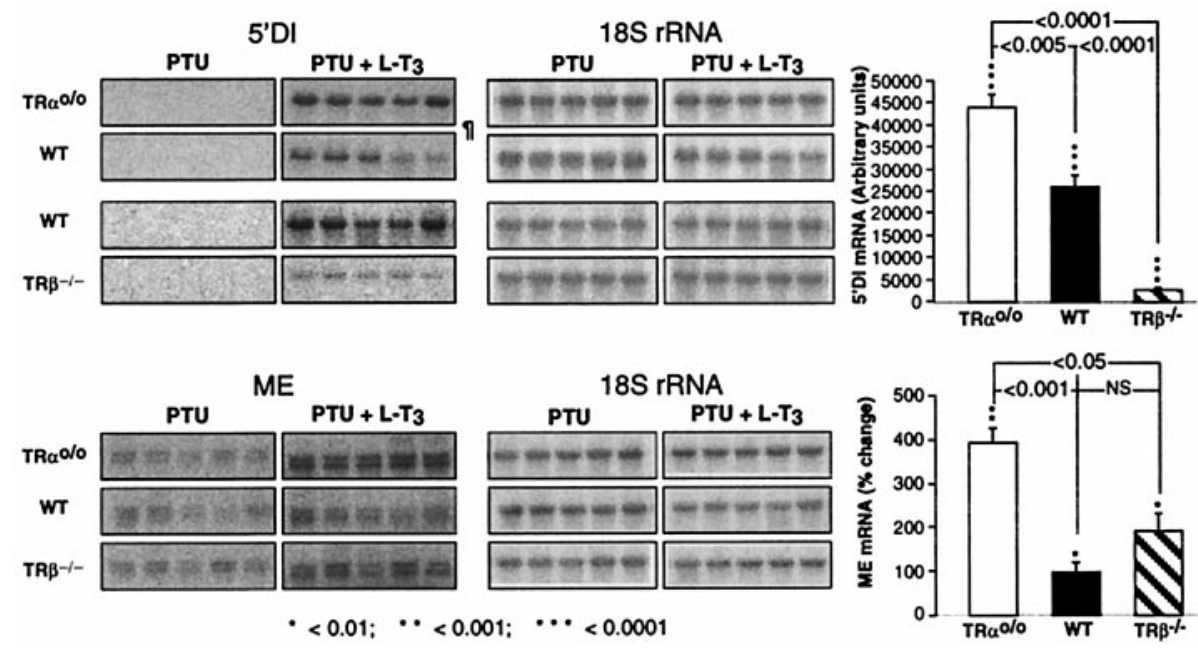

Fig. 5. Effect of TH deprivation and $L-T_{3}$ treatment on the expression of $\mathrm{TH}$-regulated genes in liver. Mice from the three genotypes were $\mathrm{TH}$ deprived (PTU) and then treated with TH (PTU + $\mathrm{L}-\mathrm{T}_{3}$ ). Liver RNAs were analyzed for their abundance in specific mRNAs by Northern blotting. Radioautographs of membranes hybridized with the two labeled CDNA probes (only five consecutive animals of each group) are shown on the left, and the percent changes induced by $\mathrm{L}-\mathrm{T}_{3}$ are plotted on the right. The membrane with RNA from $\mathrm{TR} \alpha^{\mathrm{o} / \mathrm{o}}$ and the corresponding WT mice was exposed for 3 days ( $($ I); those with RNA from the $\operatorname{TR} \beta^{-1-}$ and another set of RNAs from the same WT mice were exposed for 4 days. The same membranes were rehybridized with an 18S rRNA probe. Note the greater relative response to $\mathrm{TH}$ of $\mathrm{TR} \alpha^{\mathrm{o} / \mathrm{o}}$ mice.
In our work, we sought to determine the role of $\operatorname{TR} \alpha$ by deleting all of its isoforms and examining the resulting tissue responses to TH. Data were compared with those observed in WT mice as well as animals deficient in both $\operatorname{TR} \beta$ isoforms, manifesting signs of resistance to $\mathrm{TH}$ (20). The targeted mutation in the $\operatorname{TR} \alpha^{\mathrm{o} / \mathrm{o}}$ mouse inactivates completely not only the two full-length $T R \alpha$ gene transcripts encoded by the main promoter, but also the two shorter transcripts, $T R \Delta \alpha 1$ and $T R \Delta \alpha 2$, derived from the promoter located in intron 7 (6). However, the gene sequence for Rev-erbA $\alpha$, the TR-related protein encoded by the opposite strand of $\operatorname{TR} \alpha(18,19)$, remains intact.
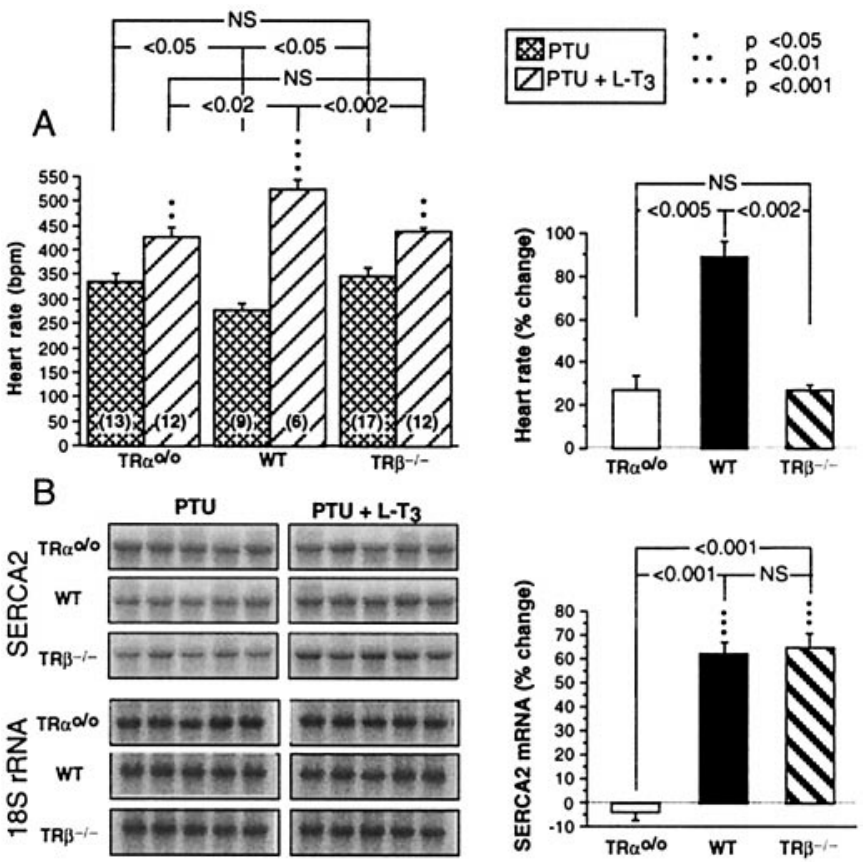

Fig. 6. Effect of $\mathrm{TH}$ deprivation and $\mathrm{L}-\mathrm{T}_{3}$ treatment on heart rate and the expression of a TH-regulated gene in heart ventricle. Mice from the three genotypes were TH-deprived (PTU) and then treated with TH (PTU + L-T T $_{3}$. (A) Mean heart rates (Left) and the percentage changes induced by the treatment with $\mathrm{L}-\mathrm{T}_{3}$ (Right). (B) The radioautographs of membranes hybridized with the SERCA2 probe (five consecutive animals of each group) are on the left, and the percentage changes induced by $\mathrm{L}-\mathrm{T}_{3}$ are plotted on the right. The same membranes were rehybridized with an 185 rRNA probe. Note the reduced responses of SRECA2 to $\mathrm{L}-\mathrm{T}_{3}$ in $\mathrm{TR} \alpha^{\mathrm{o} / \mathrm{a}}$ mice.
Similar to the TR $\alpha 1$-deficient mice reported by Wikström et al. (16), $\mathrm{TR} \alpha^{\mathrm{o} / \mathrm{o}}$ mice, of the same age and sex, had significantly lower serum $\mathrm{T}_{4}$ levels and heart rates than the respective WT animals. However, in contrast to the TR $\alpha 1$-deficient mice, the serum TSH concentrations of $\mathrm{TR} \alpha^{\mathrm{o} / \mathrm{o}}$ mice were not different from those of the WT animals, even after the analysis of more than 30 serum samples of each genotype. The maintenance of a normal serum TSH concentration despite a lower concentration of $\mathrm{T}_{4}$ suggested increased sensitivity to TH. Indeed, administration of the same dose of $\mathrm{L}_{-} \mathrm{T}_{3}$ to $\mathrm{TR} \alpha^{\mathrm{o} / \mathrm{o}}$ and WT mice had a greater suppressive effect on the serum $\mathrm{T}_{4}$ levels of the former, indicating a greater inhibition of basal TSH, even though the corresponding lower serum TSH values did not reach statistical significance. Evidence for a reduced secretion of TSH in the $\mathrm{TR} \alpha^{\mathrm{o} / \mathrm{o}}$ mice was secured from the greater $\mathrm{L}_{-} \mathrm{T}_{3}$-induced suppression of the TSH response to TRH. Together, these results indicate that the feedback regulation of the pituitary-thyroid axis of $\operatorname{TR} \alpha^{\mathrm{o} / \mathrm{o}}$ mice is more sensitive to $\mathrm{TH}$.

We then examined the sensitivity to $\mathrm{TH}$ in two peripheral tissues, liver and heart, that express predominantly the TR $\beta$ and $T R \alpha$ genes, respectively $(15,39-40, \dagger)$. Studies were carried out under the conditions of TH deprivation and TH supplementation, according to a previously tested and standardized protocol $(15,21,33)$. This protocol allows the comparison of tissue responses to the same amount of $\mathrm{TH}$ in mice that under basal conditions have different concentrations of TH. Moreover, the comparison of measurements obtained under the conditions of $\mathrm{TH}$ deprivation and full replacement increases the ability to detect modest effects of the hormone. It should be noted that this method does not achieve complete TH deficiency. However, serum TSH and $\mathrm{T}_{4}$ concentrations were not significantly different among mice of the three genotypes. Furthermore, similar levels of serum $T_{3}$ were achieved in all genotypes during $L-T_{3}$ treatment.

Again $\mathrm{TR} \alpha^{\mathrm{o} / \mathrm{o}}$ mice showed evidence for increased sensitivity to $\mathrm{TH}$ in yet another tissue, the liver. $\mathrm{L}_{-} \mathrm{T}_{3}$ given to $\mathrm{TH}$-deprived animals reduced significantly more the liver weight and serum cholesterol concentration in TR $\alpha^{\mathrm{o} / \mathrm{o}}$ as compared with WT mice. The former reflects glycogen loss through TH-mediated catabolism and the latter, TH-induced stimulated transcription of low-density lipoprotein receptor and cholesterol 7- $\alpha$ hydroxylase genes, leading to enhanced removal of low-density lipoprotein and cholesterol $(41,42)$. $\mathrm{L}_{-} \mathrm{T}_{3}$ also produced a greater increase

${ }^{+\dagger}$ Kinugawa, K., Minobe, W. A., Wood, W., Ridgway, C. E., Lowes, B. D., Baxter, J. D., Riberio, R. C. J., Long, C. S. \& Bristow, M. R. (1999) Circulation 100, Suppl. 18, I-507 (abstr.). 
in the two TH-inducible liver mRNAs, 5'DI and ME (26, 34, 43, $44)$, in TR $\alpha^{\mathrm{o} / \mathrm{o}}$ than in WT animals. It is of interest to note that under the current experimental conditions, $\mathrm{TH}$ deprivation reduced the expression of 5'DI mRNA to undetectable levels in animals of the three genotypes, whereas the reduction in $\mathrm{ME}$ mRNA was less pronounced. As is the case with the upregulation of the pituitary $T S H$ gene $(20,21,45)$, downregulation of the liver $5^{\prime} D I$ gene, during $\mathrm{TH}$ deprivation, does not appear to require the presence of TR.

$\operatorname{TR} \alpha^{\mathrm{o} / \mathrm{o}}$ mice have a significant reduction in heart rate, which increased with the administration of $\mathrm{L}_{-} \mathrm{T}_{3}$, as previously reported for $\operatorname{TR} \alpha 1$ knockout mice (16). Of interest is our finding that, in contrast to the WT and $\mathrm{TR} \beta^{-/-}$mice, the heart rate of $\mathrm{TR} \alpha^{\mathrm{o} / \mathrm{o}}$ mice did not change significantly during $\mathrm{TH}$ deprivation. This observation suggests that in absence of $\operatorname{TR} \alpha$ the heart rate is in the hypothyroid range but still can be increased by $\mathrm{TH}$, probably through the residual TR $\beta$. Nevertheless, this $\mathrm{L}_{-} \mathrm{T}_{3}$-induced increase in the $\mathrm{TR} \alpha^{\mathrm{o} / \mathrm{o}}$ mice was smaller in magnitude compared with the WT and TR $\beta^{-1-}$ mice. The effect of $\mathrm{L}-\mathrm{T}_{3}$ on SERCA2 mRNA was abolished in $\mathrm{TR} \alpha^{\mathrm{o} / \mathrm{o}}$ mice. Judging from the results obtained with the TR $\beta^{-1-}$ mice, the TH-mediated response of SERCA 2 is completely TR $\alpha$-dependent.

The observations made in the $\operatorname{TR} \beta^{-1-}$ mice are in agreement with those previously reported $(15,22)$ for $\mathrm{TR} \beta^{-1-}$ mice produced by a slightly different method of gene disruption (14). A finding not previously reported in the $\operatorname{TR} \beta$ knockout mouse is the significantly lower response of TSH to TRH at baseline and the paradoxical increase of this response after the administrations of the lower $\mathrm{L}_{-} \mathrm{T}_{3}$ dose. Although the reason for this unexpected response cannot be explained, this same effect has been reported in humans genotypically and phenotypically similar to the $\mathrm{TR} \beta^{-/-}$mice $(31,32)$ but not in humans with $\mathrm{TH}$ resistance caused by a dominant negative mutant $\operatorname{TR} \beta$ (46).

Increased sensitivity of $\mathrm{TR} \alpha^{\mathrm{o} / \mathrm{o}}$ mice to $\mathrm{TH}$ was demonstrated in the pituitary and liver, both tissues expressing predominantly the TR $\beta$ isoform. These mice differ from the TR $\alpha 1$-deficient mice that have persistent expression of $\operatorname{TR} \alpha 2$ and, presumably, $\operatorname{TR} \Delta \alpha 2$. Compensatory increases in $\operatorname{TR} \beta$ expression do not

1. Lazar, M. A. (1993) Endocr. Rev. 14, 184-193.

2. Chin, W. W. (1994) Thyroid 4, 389-393.

3. Mangelsdorf, D. J., Thummel, C., Beato, M., Herrlich, P., Schutz, G., Umesono, K., Blumberg, B., Kastner, P., Mark, M., Chambon, P., et al. (1995) Cell 83, 835-839.

4. Prost, E., Koenig, R. J., Moore, D. D., Larsen, P. R. \& Whalen, R. G. (1988) Nucleic Acids Res. 16, 6248

5. Moeller, M., Rapoport, B. \& Gavin, L. A. (1989) J. Neuroendocrinol. 5, 351-356.

6. Chassande, O., Fraichard, A., Gauthier, K., Flamant, F., Legrand, C., Savatier, P., Laudet, V. \& Samarut, J. (1997) Mol. Endocrinol. 11, 1278-1290.

7. Laudet, V., Begue, A., Henry-Duthoit, C., Joubel, A., Martin, P., Stehelin, D. \& Saule, S. (1991) Nucleic Acids Res. 19, 1105-1112.

8. Hodin, R. A., Lazar, M. A. \& Chin, W. W. (1990) J. Clin. Invest. 85, 101-105.

9. Lazar, M. A., Hodin, R. A. \& Chin, W. W. (1989) Proc. Natl. Acad. Sci. USA 86, 7771-7774.

10. Burgos-Trinidad, M. \& Koenig, R. J. (1999) Mol. Cell. Endocrinol. 149, 107-114.

11. Tagami, T., Kopp, P., Johnson, W., Arseven, O. K. \& Jameson, J. L. (1998) Endocrinology 139, 2535-2544

12. Hollenberg, A. N., Monden, T., Flynn, T. R., Boers, M. E., Cohen, O. \& Wondisford, F. E. (1995) Mol. Endocrinol. 9, 540-550.

13. Feng, P., Li, Q. L., Satoh, T. \& Wilber, J. F. (1994) Biochem. Biophys. Res. Commun. 200, 171-177.

14. Forrest, D., Hanebuth, E., Smeyne, R. J., Everds, N., Stewart, C. L., Wehner, J. M. \& Curran, T. (1996) EMBO J. 15, 3006-3015.

15. Weiss, R. E., Murata, Y., Cua, K., Hayashi, Y., Seo, H. \& Refetoff, S. (1998) Endocrinology 139, 4945-4952.

16. Wikström, L., Johansson, C., Salto, C., Barlow, C., Campos Barros, A., Baas, F., Forrest, D., Thoren, P. \& Vennstrom, B. (1998) EMBO J. 17, 455-461.

17. Fraichard, A., Chassande, O., Plateroti, M., Roux, J. P., Trouillas, J., Dehay, C., Legrand C., Gauthier, K., Kedinger, M., Malaval, L., et al. (1997) EMBO J. 16, 4412-4420.

18. Lazar, M. A., Hodin, R. A., Darling, D. S. \& Chin, W. W. (1989) Mol. Cell. Biol. 9, $1128-1136$.

19. Spanjaard, R. A., Nguyen, V. P. \& Chin, W. W. (1994) Mol. Endocrinol. 8, 286-295.

20. Gauthier, K., Chassande, O., Plateroti, M., Roux, J. P., Legrand, C., Pain, B., Rousset, B., Weiss, R., Trouillas, J. \& Samarut, J. (1999) EMBO J. 18, 623-631.

21. Weiss, R. E., Forrest, D., Pohlenz, J., Cua, K., Curran, T. \& Refetoff, S. (1997) Endocrinology 138, 3624-3629.

22. Weiss, R. E., Xu, J., Ning, G., Pohlenz, J., O’Malley, B. W. \& Refetoff, S. (1999) EMBO J. 18, 1900-1904. appear to occur at the RNA and protein levels in brain and liver of $\mathrm{TR} \alpha 1$-deficient and $\mathrm{TR} \alpha^{\mathrm{o} / \mathrm{o}}$ mice, respectively. Thus, the increased sensitivity of $\mathrm{TR} \alpha^{\mathrm{o} / \mathrm{o}}$ mice to $\mathrm{TH}$ cannot be explained by a higher level of TR $\beta$ gene expression as observed in livers of mice overexpressing $\operatorname{TR} \beta$ (33). It is thus likely that the enhanced responsiveness to $\mathrm{TH}$ in the $\mathrm{TR} \alpha^{\mathrm{o} / \mathrm{o}}$ mouse is due to the abrogation of the constitutive silencing mediated through $\operatorname{TR} \alpha 2$. This ligand-unresponsive TR has been shown to exert a weak dominant negative effect in transfected cells $(10,11)$. The ubiquitous expression of $\operatorname{TR} \alpha 2$ and its presence in tissues with predominantly $\mathrm{TR} \beta$-mediated $\mathrm{TH}$ action are expected to attenuate the effect of $\mathrm{TH}$, particularly when $\mathrm{TH}$ is present in small amounts. The enhanced effect of TH should not be manifested in tissues of $\mathrm{TR} \alpha^{\mathrm{o} / \mathrm{o}}$ mice in which $\mathrm{TH}$ action is mediated predominantly through $\mathrm{TR} \alpha 1$, as is the case in the heart. It should be noted that our data do not exclude the possible contribution of $\operatorname{TR} \alpha 1$ deficiency to the increased sensitivity to $\mathrm{TH}$, by removal of a weaker transactivator that normally competes with the TR $\beta$. The loss of the TR $\Delta \alpha$ isoforms has no effect on the observed effects on liver and pituitary because they are not expressed in these tissues ${ }^{\ddagger}$. Proof that a deficiency in TR $\alpha 2$ is the basis for the observed hypersensitivity to $\mathrm{TH}$ in mice completely deficient of TR $\alpha$ should be contained in the mouse deficient in TR $\alpha 2$ only. Although such mice do exist (47), no information is yet available regarding their precise phenotype.

We thank the following investigators for the provision of cDNA probes: 5'DI, P. Reed Larsen; ME, Vera M. Nikodem; and SERCA2, Takashi Nagaya. This work was supported in part by Grant DK 15,070 from the National Institutes of Health to S.R.; the Seymor J. Abrams Thyroid Research Center; a grant from the Ministry of Health and Welfare, Japan, to H.S.; and Grants-in-Aid for Scientific Research (B) 11472225 to Y.M. and 10470226 to H.S. from the Ministry of Education, Science, Sports and Culture, Japan.

${ }^{\ddagger \ddagger}$ Gauthier, K., Plateroti, M., Chassande, O. \& Samarut, J. (2000) in Program, (The Endocrine Society, Toronto), p. 21 (abstr.).

23. Pohlenz, J., Maqueem, A., Cua, K., Weiss, R. E., Van Sande, J. \& Refetoff, S. (1999) Thyroid 9, 1265-1271.

24. Chomczynski, P. \& Sacchi, N. (1987) Anal. Biochem. 162, 156-159.

25. Berry, M. J., Banu, L. \& Larsen, P. R. (1991) Nature (London) 349, 438-440.

26. Magnuson, M. A., Morioka, H., Tecce, M. F. \& Nikodem, V. M. (1986) J. Biol. Chem. 261, 1183-1186.

27. Murata, Y., Seo, H., Sekiguchi, K., Imai, T., Lee, J. \& Matsui, N. (1990) Mol. Endocrinol. 4, 693-699.

28. Grubbs, F. (1969) Technometrics 11, 1-21

29. Grubbs, F. E. \& Beck, G. (1972) Technometrics 14, 847-854.

30. Johansson, C., Göthe, S., Forrest, D., Vennsrtöm, B. \& Thorén, P. (1999) Am. J. Physiol. 276, H2006-H2012.

31. Refetoff, S., Degroot, L. J. \& Barsano, C. P. (1980) J. Clin. Endocrinol. Metab. 51, 41-45.

32. Takeda, K., Sakurai, A., DeGroot, L. J. \& Refetoff, S. (1992) J. Clin. Endocrinol. Metab. 74, $49-55$.

33. Hayashi, Y., Mangoura, D. \& Refetoff, S. (1996) Mol. Endocrinol. 10, 100-106.

34. Menjo, M., Murata, Y., Fujii, T., Nimura, Y. \& Seo, H. (1993) Endocrinology 133, 2984-2990.

35. Schwartz, H., Lazar, M. \& Oppenheimer, J. (1994) J. Biol. Chem. 269, 24777-24782.

36. Lazar, M. A. \& Chin, W. W. (1990) J. Clin. Invest. 86, 1777-1782.

37. Yu, V. C., Delsert, C., Andersen, B., Holloway, J. M., Devary, O. V., Naar, A. M., Kim, S. Y., Boutin, J. M., Glass, C. K. \& Rosenfeld, M. G. (1991) Cell 67, 1251-1266.

38. Kliewer, S. A., Umesono, K., Mangelsdorf, D. J. \& Evans, R. M. (1992) Nature (London) 355, 446-449.

39. Falcone, M., Miyamoto, T., Fierro-Renoy, F., Macchia, E. \& DeGroot, L. J. (1992) Endocrinology 131, 2419-2429.

40. White, P. \& Dauncey, M. J. (1999) J. Mol. Endocrinol. 23, 241-254.

41. Ness, G. C., Pendelton, L. C. \& Zhao, Z. (1994) Biochim. Biophys. Acta. 1214, 229-233.

42. Ness, G. C. \& Lopez, D. (1995) Arch. Biochem. Biophys. 323, 404-408.

43. Zilz, N. D., Murray, M. B. \& Towle, H. C. (1990) J. Biol. Chem. 265, 8136-8143.

44. Dozin, B., Magnuson, M. A. \& Nikodem, V. M. (1986) J. Biol. Chem. 261, 10290-10292.

45. Göthe, S., Wang, Z., Ng, L., Kindblom, J. M., Campos Barros, A., Ohlsson, C., Vennström, B. \& Forrest, D. (1999) Genes Dev. 13, 1329-1341.

46. Refetoff, S., Weiss, R. E. \& Usala, S. J. (1993) Endocr. Rev. 14, 348-399.

47. Forrest, D. \& Vennström, B. (2000) Thyroid 10, 41-52. 